\title{
Factors Influencing The Readiness Of Government Financial Personnel In Migrating Towards Accrual Accounting
}

\author{
Moawiah Awad Alghizzawi, Rosnia Masruki
}

\begin{abstract}
Jordan's migration towards accrual accounting is aimed at to be completed by year 2021, being as one of its government's fiscal reform steps. However, this process is not progressing well within the government of Jordan due to the lack of improvement in performance. It is important to prepare the government's financial personnel for the migration in order to ensure a successful migration process. Moreover, individual readiness factors associated with the acceptance or rejection of migration towards accrual accounting should be considered before the actual migration process takes place. Thus, this research aims to address the influence of social relationships at the workplace and job satisfaction on the readiness of Jordanian government financial personnel to determine their reaction regarding the migration towards accrual accounting. Following the quantitative method, the researcher distributed 375 questionnaires to the government financial personnel working in the Jordanian Ministry of Finance (JMOF), and a total of 331 questionnaires were returned, hence achieving a $88 \%$ response rate. The results of the research indicate a positive significant association between social relationships at the workplacel job satisfaction and the readiness of Jordanian government financial personnel to migrate towards accrual accounting. Several limitations and potential areas for future studies are discussed in the last section of the paper.
\end{abstract}

Index Terms: Keywords: Accrual Accounting, Jordan, Readiness of Government Financial Personnel, Social Relationships at the Workplace, Job Satisfaction

\section{INTRODUCTION}

According to [17], public demand for major enhancements in government undertakings has led to substantial changes in the organization, management, and accounting functions of governments globally. Governmental accounting reform is considered an important prerequisite for successful implementation of any other organizational or managerial reform. This is because a reformed accounting system is able to provide relevant and accurate financial information to support any other reform [19]. Governmental accounting reform involves the migration towards accrual accounting that allows for higher quality and quantity of accounting information, which improves transparency and accountability, resulting in a better process for decision making [12] and [40]. Accrual

Revised Manuscript Received on April 19, 2019.

Moawiah Awad Alghizzawi, Faculty of Economics and Muamalat, Universiti Sains Islam Malaysia, Nilai, Malaysia.(email: Moalgzzawi@gmail.com)

Rosnia Masruki, Faculty of Economics and Muamalat, Universiti Sains Islam Malaysia, Nilai, Malaysia.(email: rosnia@usim.edu.my) accounting fulfills the demand for efficiency, transparency, and performance management [18], which would lead to a high quality, consistent and comprehensive financial information in the government's accounting reports.

Consequently, in the context of governmental accounting reform, the JMOF had decided in 2015 to migrate from cash accounting towards accrual accounting and its expecting to be fully implementing in Jordan by year 2021 [49]. The decision taken was considered a step towards the implementation of international public sector accounting standards (IPSASs) in Jordan. Following that, the JMOF stated that the process of implementing the IPSASs was not progressing well due to the lack of performance improvement within the Jordanian government. In this regard, the Jordanian Finance Minister "Omar Malhas" stressed the need to increase the readiness of government financial personnel within the government of Jordan to keep pace with the fiscal reform decisions taken by the government of Jordan in general and in particular, the migration towards accrual accounting-IPSASs [30].

[14] found that the risks associated with the migration towards accrual accounting are not given due consideration by the governments, despite its complexity. He noted that one of the challenges confronted the New Zealand government in its migration towards accrual accounting was the lack of readiness of the government financial personnel. As highlighted by [10], regardless of the extent of the organizational change, it should be managed properly because it involves moving from a familiar towards an unfamiliar situation. [4] added that readiness of the people involved in the organizational change plays an essential role in ensuring its effective and successful implementation. Therefore, individual readiness factors associated with the acceptance or rejection of organizational change (migration towards accrual accounting) should be considered before the actual change takes place [6].

In Jordan, a few prior studies were conducted on the migration towards accrual accounting through empirical evidence. For instance, the study of [3] revealed that organizational commitment plays a positive role in raising the readiness of government financial personnel in the migration towards accrual accounting in the government of 
Jordan. The same issue was addressed by several prior studies and it was concluded with several factors influencing the readiness of government financial personnel in the migration towards accrual accounting. For example, human resources capability and information technology were found to be important factors by [28], [2] and [45] to raise the readiness of government financial personnel in the context of Indonesia, Malaysia and Thailand respectively. Additional important factors associated with readiness of financial personnel in the migration process such as change valence, task knowledge and task availability were found by [29] study in Malaysia.

However, none of the abovementioned studies addressed the role of psychological needs (i.e. social relationships at the workplace and job satisfaction) in developing government financial personnel's attitudes and behaviors during the organizational change (migration towards accrual accounting), which may affect the government financial personnel's cognition level. Thus, after conducting a review of the relevant literature, this research intends to fill this void by addressing the role of social relationships at the workplace and job satisfaction in developing government financial personnel's readiness in the migration towards accrual accounting system. Thus, the primary objectives of this research have been determined as follows:

To address the influence of social relationships at the workplace on the readiness of Jordanian government financial personnel to migrate towards accrual accounting.

To address the influence of job satisfaction on the readiness of Jordanian government financial personnel to migrate towards accrual accounting.

\section{LITERATURE REVIEW}

[16] refers to organizational change as a shift from one situation to another, or it involves replacing the current structures with new ones. Organizational change takes place between two different times such that the organization could be distinguished pre and post-transition [8]. According to [1] and [23], organizational change can be both disorganized and tense as the shift from a known to an unknown territory could lead to uncertainties, fear, and doubts. As a result, the people in the organization may have various thoughts, feelings, and attitude regarding the change because it may require them to learn and relearn, which may be challenging and hence inducing apprehension and nervousness.

[9] emphasized the critical role of individuals' behaviors and beliefs in ensuring effective organizational change. [5] stated that (p.67), "attitudes reflect a person's tendency to feel, think or behave in a positive or negative manner towards the object of the attitude". Therefore, numerous studies have examined the impact of good behaviors and attitudes on organizational change e.g. [21] and [36]. Change programs may cause feelings of delight, enthusiasm, resentment, and worry among the people in the organization [46]. Thus, how employees feel about their new circumstances have a major impact on the purpose and aims of organizational change.

As stressed by [43], it is imperative to ensure that the employees are ready prior to, during, and subsequent to the achieved by meeting their basic needs including implementation of the change program. This can be

psychological needs [15]. Establishing employees' readiness for change can help prevent any potential resistance from them when change is implemented later. Therefore, it is important for organizations to assess individuals' readiness for change and also to understand the related factors influencing the individuals' readiness for change according to [36].

Accordingly, the concept of readiness for change in the context of this research is the readiness of government financial personnel to migrate from cash accounting towards accrual accounting.

\section{A.Social Relationships at the Workplace}

The concept of social relationships at the workplace refers to the interaction of the employees with their supervisors and colleagues in their organization. Their interactions and associations manifest in the employees' outlook, feelings, and behaviors and can have either a negative or a positive impact on the employees. Positive associations will culminate in positive outcomes including decreased work effort as well as the feeling of contentment and happiness, and these necessitate dynamic interactions among the employees [38], [35] and [26]. On the contrary, negative relations that include disrespect and recurring hostility will have a negative impact on employees and their attitude, and ultimately on the entire organization [20]. According to [39], it will lead to apathy towards activities in the organization, which include their readiness to accept change. [42] noted that informal relations among employees influence a wide number of significant outcomes for those employees, such as their career progression and performance.

Nevertheless, numerous prior research works found a positive influence of social relationships at the workplace on organizational change, such as the study by [43] on "public higher education institutions" in Pakistan. Similarly, research carried out by [38] in northern Utah, Canada found a positive significant association between social relationships at the workplace and employees' readiness towards change. In addition, another prior study carried out by [35] in two northern Utah counties discovered social relationships at the workplace have a positive significant influence on readiness towards change. In the USA, research showed a positive significant impact of social relationships at the workplace on employees' readiness towards change [26]. Thus, in view of the findings of prior literature, the following hypothesis has been developed:

H1: Social relationships at the workplace positively influence the readiness of Jordanian government financial personnel to migrate towards accrual accounting.

\section{B.Job Satisfaction}

One factor that can influence readiness for change is job satisfaction. [13] explained job satisfaction as the attitude of employees towards their job and rewards as well as the social, organizational, and physical characteristics of the working environment. [47] mentioned that as a result of job satisfaction that fulfills employees' personal needs; they are

Published By: 
willing to exert extra effort on behalf of the organization. Thus, the higher employee satisfaction will positively reflect on the organizations' work, including organizational change.

It has been shown in some studies that job satisfaction has a positive influence on readiness for change, such as the study by [24] in India, which discovered a significant influence. Similarly, job satisfaction was proven to have a significant positive relationship with readiness towards change in a study on an Indonesian dairy product company by [7]. Moreover, [33] discovered that individuals' higher level of readiness for change is characterized by positive job satisfaction. Thus, the second hypothesis has been developed:

$\mathrm{H} 2$ : Job satisfaction positively influences the readiness of Jordanian government financial personnel to migrate towards accrual accounting.

\section{THE UNDERLYING THEORY}

\section{A.Maslow's Hierarchy of Need Theory (1954)}

Maslow's Theory [37] is supported when analyzing the psychological needs for employee change readiness. According to this theory, human needs are formed in an ascending hierarchical pyramid, and such needs influence individuals' attitudes and behaviors. Each of the five levels (see Table I) in the hierarchy builds upon the previous level(s), with the most basic human needs forming the base of the pyramid. The variables in this research are related to employees' needs, which are consistent with the needs described in Maslow's framework. Those variables play a role in employees' readiness towards the organization and their career such that they will foster desirable behaviors and attitudes for organizational change. Satisfied needs will motivate employees to contribute proactively to the organizational change program. Self-actualization will be attained by the employees upon the fulfillment of all their physiological, financial, security, socialization, and esteem needs.

Table I : Maslow's Hierarchy of Need Level Compared to Employee's Needs

\begin{tabular}{ll}
\hline Employee's Needs & $\begin{array}{l}\text { Maslow's Hierarchy of } \\
\text { Need Levels }\end{array}$ \\
\hline Pay/Wages/Rewards & Level 1: Psychological need \\
Promotion/Tenure & Level 2: Need for safety \\
Social Relationships in & Level 3: Need for belonging \\
Workplace & \\
Job satisfaction & Level 4: Self-esteem \\
Training and skills & Level $5:$ Self-actualization \\
development & \\
Source:Adapted from [43]. &
\end{tabular}

Therefore, Maslow's Theory [37] can be employed for explaining the effect of psychological needs, namely social relationships at the workplace and job satisfaction, on Jordanian government financial personnel with a view of influencing their behaviors and attitudes (readiness) to migrate from cash accounting towards accrual accounting.

\section{METHODOLOGY}

This research followed the quantitative method by employing the questionnaire to collect the needed data using the simple random sampling method. The questionnaire used was adapted from previous studies [35], [39], [41], [44], [32] and [11] conducted in the context of the variables used in this research. Moreover, this research identified the government financial personnel working in the JMOF as the research's population because those financial personnel are responsible for the migration towards accrual accounting and they will be using the system directly after it is implemented. The size of the population based on the Jordanian General Budget Department [22] was 1948 financial personnel and hence, the sample of this research comprised 321 financial personnel [31].

\section{A.Pilot Study}

In this research, a pilot study was carried out to assess the adequacy of the research instrument and to identify the potential problems that might occur during the process of data collection [48]. In addition, the pilot study was performed to increase the precision of the final result as well as to get a valid and reliable instrument.

Thus, the researcher distributed 60 questionnaires at the JMOF to test the reliability and validity of the research instrument as well as to determine the potential time needed to conduct the main research. Hence, the reliability of each construct was calculated using the internal consistency criteria of the scales (Cronbach's alpha reliability coefficients). With regard to validity, based on the result of the pilot study, the researcher took into account the comments and suggestions obtained to improve the final form of the questionnaire. Table II below presents the reliability coefficient for all the constructs.

Table II: Cronbach's Alpha Results

\begin{tabular}{lll}
\hline Variables & No. of items & Cronbach's alpha \\
\hline Social & 8 & 0.900 \\
Relationships at the & & \\
Workplace & & \\
Job Satisfaction & 7 & 0.793 \\
Readiness of & 7 & 0.856 \\
Govermment & & \\
Financial Personnel & & \\
\hline
\end{tabular}

As shown in Table II above, the Cronbach's alpha results for all the constructs are higher than the acceptable threshold, which is .60 as suggested by [25]. It can be seen that the reliability coefficient for all the constructs ranged from .79 to .90 .

\section{B.Response Rate}

A total of 375 questionnaires were distributed to financial personnel enrolled at the Jordanian General Budget Department [22]. Each questionnaire had been verbally scanned to clean the data from any missing responses. It is recommended to exclude a respondent who has a missing response of $50 \%$ or higher [25]. Therefore, all questionnaires were verified immediately with the 
International conference on Recents Advancements in Engineering and Technology (ICRAET-18) |15th and 16th March 2019|Siddhartha Institute of Technology \& Sciences, Telangana, India.

participants. A total of 331 questionnaires were collected and used for subsequent analysis, giving a response rate of $88 \%$. This high rate was achieved because the questionnaires were personally distributed by hand. Therefore, all of the questionnaires that were collected were used in this research.

\section{FINDINGS}

\section{A.Sample Profile}

Table III demonstrates that 205 or $61.9 \%$ of the financial personnel were male, while the rest or $38.1 \%$ were female. For experience, Table III demonstrates that the majority of the financial personnel (44.4\%) had $11 ? 20$ years of experience, while the lowest belonged to the financial personnel with more than 31 years of experience $(0.3 \%)$. With regard to the educational level of the financial personnel, the majority of them had a bachelor's degree $(61.9 \%)$, followed by a two years' diploma $(15.1 \%)$, and the lowest belonged to the financial personnel with a doctorate degree $(2.7 \%)$.

In addition, Table III demonstrates that the majority of financial personnel' education background was Accounting and Finance $(69.5 \%)$, and the lowest belonged to the financial personnel with Law and Political Science background $(1.8 \%)$. Finally, Table III demonstrates that the majority of financial personnel' income was between JOD 501 and JOD $1000(76.1 \%)$, and the lowest belonged to the income group of JOD 2000 and above (0.6\%).

Table III: Sample Profile

\begin{tabular}{|c|c|c|c|}
\hline \# & Profile & Frequency & Percentage \\
\hline \multirow[t]{2}{*}{ Gender } & Male & 205 & 61.9 \\
\hline & Female & 126 & 38.1 \\
\hline \multirow[t]{4}{*}{ Experience } & Under 10 years & 100 & 30.2 \\
\hline & $11-20$ years & 147 & 44.4 \\
\hline & 21-30 year & 83 & 25.1 \\
\hline & 31 and above & 1 & 0.3 \\
\hline \multirow[t]{5}{*}{ Education } & High School & 18 & 5.4 \\
\hline & Diploma & 50 & 15.1 \\
\hline & Bachelor & 205 & 61.9 \\
\hline & Master & 49 & 14.8 \\
\hline & Doctorate & 9 & 2.7 \\
\hline \multirow[t]{5}{*}{ Background } & $\begin{array}{l}\text { Accounting and } \\
\text { finance }\end{array}$ & 230 & 69.5 \\
\hline & $\begin{array}{l}\text { Law and political } \\
\text { science }\end{array}$ & 6 & 1.8 \\
\hline & Bushiness & 33 & 10 \\
\hline & $\begin{array}{l}\text { Public } \\
\text { administration }\end{array}$ & 18 & 5.4 \\
\hline & Others & 44 & 13.3 \\
\hline \multirow[t]{5}{*}{ Income } & Bellow 500 JOD & 24 & 7.3 \\
\hline & 501-1000 JOD & 252 & 76.1 \\
\hline & 1001-1500 JOD & 48 & 14.5 \\
\hline & 1501-2000 JOD & 5 & 1.5 \\
\hline & Above $2000 \mathrm{JOD}$ & 2 & 0.6 \\
\hline
\end{tabular}

\section{B.Descriptive Analysis}

The descriptive analysis is presented in Table IV to explain the salient characteristics of the sample in relation to the variables included in the research.
Table IV: Descriptive Analysis

\begin{tabular}{lllll}
\hline$\#$ & & $\begin{array}{l}\text { Mean } \\
\text { SRW }\end{array}$ & $\begin{array}{l}\text { Mean } \\
\text { JS }\end{array}$ & $\begin{array}{l}\text { Mean } \\
\text { RGAP }\end{array}$ \\
\hline Min & Statistic & 1.00 & 1.57 & 1.71 \\
Max & Statistic & 5.00 & 5.00 & 5.00 \\
Mean & Statistic & 3.8236 & 3.7695 & 3.7566 \\
Std. Dev & Statistic & .63455 & .66990 & .61706 \\
Skewness & Statistic & -.783 & -.511 & -.563 \\
& Std. Error & .134 & .134 & .134 \\
Kurtosis & Statistic & 1.681 & .556 & 1.042 \\
& Std. Error & .267 & .267 & .267 \\
\hline
\end{tabular}

SRW is social relationships at the workplace, JS is job satisfaction, and RGFP is readiness of government financial personnel.

An above average score of 3.8 was recorded for social relationships at the workplace (see Table IV), indicating that good interpersonal relationships are maintained among the JMOF financial personnel with their colleagues, leaders, and the people they meet at the workplace. According to the financial personnel, the JMOF has a pleasant working environment, it provides them with the opportunity to get to know different people from various backgrounds, and the environment fosters teamwork and communication. Therefore, they have opportunities to share their experiences with co-workers and mingle at the workplace.

A slightly above mid-point score of 3.7 was achieved for job satisfaction, implying most of the JMOF financial personnel have job satisfaction at the ministry. The financial personnel are satisfied with their work, colleagues, supervisors, and prospect for promotion. In addition, they are satisfied with the monetary rewards given to them by the JMOF.

Regarding the readiness of the JMOF financial personnel to migrate from cash accounting towards accrual accounting, a slightly above mid-point score of 3.7 (see Table IV) was achieved, indicating that the majority of them are ready for the migration. They look forward to the change to accrual accounting and are supportive of the change. Moreover, the JMOF financial personnel are willing to do anything that is needed to realize the migration towards accrual accounting. This is consistent with their stand to support new ideas and habit of suggesting new work approaches.

Data normality was established using the test for skewness and kurtosis. According to [27], a skewness value that is below 2 and kurtosis below 7 indicate sufficient univariate normality. On that basis, the data in this research have sufficient normality.

\section{C.Multiple Regression Analysis}

Multiple regression analysis is used to find out the quantitative prediction of several independent variables on the dependent variable. In other words, how the independent variables explain the dependent variable [25]. Hence, the concern of this research is how the social relationships at the workplace and job satisfaction as independent variables 
predict the readiness of government financial personnel to migrate towards accrual accounting as a dependent variable. As such, multiple regression analysis was performed and the results are shown in Table $\mathrm{V}$. The p-value is smaller than $0.001(\mathrm{p}<0.05)$ indicating that the model is significant. The results also show that there is a positive significant association between the readiness of government financial personnel and social relationships at the workplace. Therefore, $\mathrm{H} 1$ is accepted. This result is consistent with the prior research [43], [26], [35] and [38] which found a positive significant association between social relationships at the workplace and individuals' readiness towards change.

In addition, Table $\mathrm{V}$ indicates that there is a positive significant association between the readiness of government financial personnel and job satisfaction. Therefore, $\mathrm{H} 2$ is accepted. This result is consistent with the prior research [24], [7] and [33] which found a positive association between job satisfaction and individuals' readiness towards change.

Table V: Regression Analysis

\begin{tabular}{|c|c|c|c|c|c|}
\hline \multirow[t]{2}{*}{ Model } & \multicolumn{2}{|c|}{$\begin{array}{l}\text { Unstandardiz } \\
\text { ed } \\
\text { Coefficients }\end{array}$} & \multirow{2}{*}{$\begin{array}{l}\text { Standard } \\
\text { ized } \\
\text { Coefficie } \\
\text { nts } \\
\text { Beta }\end{array}$} & \multirow[t]{2}{*}{$\mathbf{t}$} & \multirow[t]{2}{*}{$\begin{array}{l}\text { Sig } \\
\text {. }\end{array}$} \\
\hline & $\mathbf{B}$ & $\begin{array}{l}\text { Std. } \\
\text { Error }\end{array}$ & & & \\
\hline Constant & $\begin{array}{l}1.11 \\
1\end{array}$ & .179 & & 6.197 & .000 \\
\hline $\begin{array}{l}\text { Mean } \\
\text { SRW }\end{array}$ & .492 & .047 & .506 & 10.479 & .000 \\
\hline Mean JS & .203 & .044 & .220 & 4.559 & .000 \\
\hline \multicolumn{6}{|c|}{ a. Dependent Variable: mean RGFP } \\
\hline \multicolumn{2}{|c|}{$\begin{array}{l}\text { R Square } \\
\text { Adjusted R-Square }\end{array}$} & \multicolumn{2}{|l|}{41.1} & & \\
\hline \multicolumn{2}{|c|}{ F-Value (Sig. value) } & \multicolumn{2}{|c|}{$114.507 *(0.000)$} & & \\
\hline
\end{tabular}

The positive significant associations of social relationships at the workplace and job satisfaction with the readiness of government financial personnel are consistent with the Maslow's Theory [37]. It suggests that social relationships at the workplace and job satisfaction have a positive effect on employees' readiness towards their organization and their career, thus fostering desirable attitudes and behaviors during change in the organization.

\section{CONCLUSION}

This research was motivated by the gap in the existing literature which showed that during the migration process, the organizational change needs proper attention due to the shift in the situation from a familiar towards an unfamiliar situation. Thus, individuals' readiness is an important and dominant factor for promoting permanent, effective and successful organizational change programs. Moreover, this research demonstrated that social relationships at the workplace and job satisfaction are crucial predictors of employees' readiness towards organizational change, which in this research is the migration from cash accounting towards accrual accounting. The results indicated that social relationships at the workplace and job satisfaction positively influence the readiness of Jordanian government financial personnel to migrate towards accrual accounting.

The obtained results add to the body of knowledge concerning accrual accounting and organizational change. It is also the earliest quantitative research to examine the association between social relationships at the workplace/ job satisfaction and the readiness of Jordanian government financial personnel to migrate towards accrual accounting. Furthermore, given the considerable shortage of recent studies that link the role of social relationships at the workplace / job satisfaction and individuals' readiness towards change, this research updated the knowledge regarding the association between these variables through empirical evidence. In addition, it is important that the findings of this research be taken into consideration by decision-makers in the government of Jordan to develop the readiness of financial personnel to migrate towards accrual accounting in all government bodies.

However, this research has some limitations. First, this research is constrained by the lack of studies related to this topic in developing countries. In fact, it is the first research in this area conducted in Jordan and the Middle East region. Therefore, more studies are required to confirm the results obtained by this research. Second, this research considered specific predictors only, which are social relationships at the workplace and job satisfaction. Since these variables are found to be very important in predicting the readiness of Jordanian government financial personnel to migrate towards accrual accounting, it would be worthwhile to incorporate other predictors or other measures. In addition, future studies may consider other psychological needs such as job involvement that relates to the sense of attachment that employees have towards their job [34]. This sense of attachment means that employees are identifiable by their job, thus indicating the significance of a job in a person's life. Job involvement relates to a person's psychological behavior, reflecting his or her attitude and behavior. Lastly, in accordance with Maslow's Theory [37] and JMOF's report [30], future studies may consider the role of training and skills development within the government of Jordan in developing government financial personnel's readiness in the migration towards accrual accounting system.

\section{REFERENCES}

1. Abrahamson, E. (2000). Change without Pain. Harvard business review, vol. 78, no. 4, pp. 75-79.

2. Ahmad, N. N. (2016). Investigating the Factors Influencing Users' Resistance towards Accrual Accounting. Procedia Economics and Finance, 35, 17-26.

3. Alghizzawi, M. A., \& Masruki, R. B. (2019). Organizational Commitment and the Readiness towards Accrual Accounting: The Moderating Role of Job Satisfaction. International Journal of Asian Social Science, 9 (2), 169-178. 

Making change permanent: A model for institutionalizing change interventions. Research in Organizational Change and Development, vol. 12, pp. 97-128.

5. Arnold, J., Cooper, C., \& Robertson, I. (1995). Work Psychology: Understanding Human Behaviour in the Workplace. London: Pitaman Publishing.

6. Atan, R., \& Yahya, F. M. (2015). Accrual Accounting Change: Malaysian Public Sector Readiness. Journal of Management Research?, 7 (2), 459.

7. Azra, Etikariena, \& Haryoko. (2016). The effect of job satisfaction in employee's readiness for change. In H. M. Amarina Ashar Ariyanto, Diversity in Unity: Perspectives from Psychology and Behavioral Sciences (p. 648). London: Taylor \& Francis Group.

8. Barnett, W., \& Carroll, G. (1995). Modelling Internal Organizational Change. Annual Review of Sociology, vol. 21, no. 1, pp. 217.

9. Beer, M., \& Walton, E. (1990). Developing the competitive organization: Interventions and strategies. American Psychologist, vol. 45, no. 2, pp. 154-161.

10. Bennett, J. L. (2001). Change Hygiene. HR Magzine, vol. 46 , no. 8 , pp. 149 .

11. Bosmans, Anick, Pieters, R., \& Baumgartner, H. (2010). The Get Ready Mind-Set: How Gearing Up for Later Impacts Effort Allocation Now. Journal of Consumer Research, 37, 98-107.

12. Broadbent, J., \& Guthrie, J. (2008). Public sector to public service: 20 years of contextual accounting research. Accounting, Auditing \& Accountability Journal, 21(2): 129-180.

13. Çekmecelio?lu, H. G., Günsel, A., \& Uluta?, T. (2012). Effects of Emotional Intelligence on Job Satisfaction: An Empirical Study on Call Center Employees. ProcediaSocial and Behavioral Sciences, 58, 363-369.

14. Champoux, M. (2006). Accrual accounting in New Zealand and Australia: Issues and Solution. Federal Budget Policy Seminar, 2-3.

15. Chang, E. (1999). Career Commitment as a Complex Moderator of Organizational Commitment and Turnover Intention. Human Relations, 52 (10): 1257-1278.

16. Chonko, L. (2004). Organizational readiness for change, individual fear of change, and sales manager performance: an empirical investigation. Journal of Personal Selling and Sales Management, vol. 24, no. 1, pp. 7-17.

17. Christiaens, J., \& Rommel, J. (2008). Accrual accounting reforms: only for businesslike governments. Financial Accountability \& Management?, 24 (1), 59-75.

18. Christiaens, J., Reyniers, B., \& Rollé, C. (2010). Impact of IPSAS on reforming governmental financial information systems: a comparative study. International Review of Administrative Sciences, 76 (3): 537-554.

19. Christiaens, M. (2007). What we might know but aren't sure about public sector accrual accounting. Australian Accounting Review, Vol. 17, No. 1, pp.51-65.

20. Dillard, J., \& Fritz, J. (1995). Interpersonal relationships and organizational performance. Annual Convention of the Western Speech Communication Association. Portland OR: Google Scholar.

21. Eby, L., Adams, D., Russell, J., \& Gaby, S. (2000). Perceptions of organizational readiness for change: Factors related to employees' reactions to the implementation of team-based selling. Human Relations, vol. 53, no. 3, pp. 419-442.

22. General Budget Department. (2018). Draft general budget law for the year 2018, Jordan. pp: 50. Retrieved from http://www.gbd.gov.jo/GBD/en/Budget/Draft/draftgeneral-budget-law
4. Armenakis, A. A., Harris, S. G., \& Feild, H. S. (1999).

23. Gleick, J. (1987). Chaos: Making a New Science. London: Sphere Book Ltd.

24. Gupta, S., \& Singla, A. (2016). Organizational change and job satisfaction: An analysis of mediating effect of organizational trust. Indian Journal of Commerce and Management Studies, 7 (3), 7.

25. Hair, J. F., Black, C., W., Babin, J., B., Anderson, \& Rolph, E. (2010). MultivariateData Analysis (7th Edition). New Jersey: Pearson education.

26. Hanpachern, C., Morgan, G., \& Griego, O. (1998). An extension of the theory of margin: A framework for assessing readiness for change. Human Resource Development Quarterly, vol. 9, no. 4, pp. 339.

27. Ho, R. (2006). Handbook of univariate and multivariate data analysis and interpretation with SPSS. United States of Americ: Chapman \& Hall/CRC: Taylor \& Francis Group.

28. Indriani, M., Mulyany, R., Nadirsyah, N., \& Munandar, W. (2018). Readiness of Local Government in the Implementation of Accrual Accounting: The Case of Local Government in Aceh, Indonesia. Jurnal Dinamika Akuntansi dan Bisnis, 5 (1), 87-100.

29. Ismail, S., Siraj, S. A., \& Baharim, S. (2018). Implementation of accrual accounting by Malaysian federal government: are the accountants ready?. Journal of Accounting \& Organizational Change, 14 (2), 234 247.

30. Jordanian Ministry of Finance. (2016). The implementation of "financial reform" requires further raising the capacity of government financial cadres. pp: 1. Retrieved from http://mof.gov.jo/تفاصيلالخبر/الأخبار/مركز الاعلام/tabid/118/A rticleId/128/l

31. Krejcie, R. V., \& Morgan, D. W. (1970). Determining sample size for research activities. Educ Psychol Meas, 30 (3), 607-610.

32. Kwahk, K. Y., \& Lee, J. N. (2008). The role of readiness for change in ERP implementation: Theoretical bases and empirical validation?. Information \& Management, 45 (7),474- 481

33. Lipi?ska-Grobelny, A., \& Papieska, E. (2012). Readiness for change and job satisfaction in a case of lean management application-A comparative study? International journal of occupational medicine and environmental health, 25 (4), 418-425.

34. London, M. (1983). Toward a Theory of Career Motivation. Academy of Management Review, 8 (4): 620-630.

35. Madsen, S., Miller, D., \& John, C. (2005). Readiness for organizational change: Do organizational commitment and social relationships in the workplace make a difference?. Human Resource Development Quarterly, vol. 16, no. 2, pp. 213.

36. Martin, M. (1998). Trust Leadership. Journal of Leadership and Organizational Studies, Vol, 5, no. 3, pp. 41-49.

37. Maslow, A. (1954). Motivation and Personality. New York: Harper \& Row.

38. Miller, D., Madsen, S., \& John, C. (2006). Readiness for Change: Implications on Employees' Relationship with Management, Job Knowledge and Skills, and Job Demands. Journal of Applied Management and Entrepreneurship, vol. 11, no. 1, pp. 3.

39. Morrison, R. L. (2008). Negative relationships in the workplace: Associations with organisational commitment, cohesion, job satisfaction and intention to turnover?. Journal of Management \& Organization, 14 (4), 330-344. 
40. Ouda, H. (2004). Basic requirements model for successful implementation of accrual accounting in the public sector. The International Consortium on Governmental Financial Management, 4 (1): 78-99.

41. Schneider, Benjamin, Salvaggio, A. N., \& Brent Smith, D. (2003). Which Comes First: Employee Attitudes or Organizational Financial and Market Performance? Journal of Applied Psychology, 88, 836-851.

42. Seibert, S., Kraimer, M., \& Liden, R. (2001). A social capital theory of career success. Academy of Management Journal, 44, 219-237.

43. Shah, N. (2009). Determinants of employee readiness for organisational change?. Doctoral dissertation, Brunel University.

44. Smith, P. C. (1969). The measurement of satisfaction in work and retirement: A strategy for the study of attitudes. Chicago: Rand McNally.

45. Upping, P., \& Oliver, J. (2012). Thai public universities: modernisation of accounting practices. JournalofAccounting\&OrganizationalChange, Vol.8 No.3, 403-430.

46. Vakola, M., Tsaousis, I., \& Nikolaou, I. (2003). The role of emotional intelligence and personality variables on attitudes towards organizational change. Journal of Managerial Psychology, vol. 19, 88-110.

47. Van Scotter, J. (2000). Relationships of task performance and contextual performance with turnover, job satisfaction, and affective commitment. Human Resource Management Review, vol.10, no. 1, 79-95.

48. Van Teijlingen, E., \& Hundley, V. (2002). The Importance of Pilot Studies. Nursing Standard, 16 (40), 33-36.

49. Wiggins, J. D., Biggs, \& Al-Bokairat, O. (2016). Jordan: Assessment of public expenditure and financial accountability PEFA. Spain: AECOM International Development Europe SL. pp: 75. 